\title{
Investigation of Physical Education and Sports Students' Attitudes Towards E-Learning
}

\author{
Tuncay Öktem ${ }^{1}$ \\ ${ }^{1}$ School of Physical Education and Sport, Bayburt University, Bayburt, Turkey \\ Correspondence: Tuncay Öktem, School of Physical Education and Sport, Bayburt University, Bayburt, Turkey. \\ E-mail: tuncayktm@gmail.com
}

Received: May 4, 2020 Accepted: June 8, 2020 Online Published: June 19, 2020

doi:10.5539/jel.v9n4p49 URL: https://doi.org/10.5539/jel.v9n4p49

\begin{abstract}
The present study aimed to investigate the attitudes of university students who have received sports education towards E-learning. Quantitative research model was applied in the research. The population of the study consisted of 315 students who were selected via random sampling method, at Bayburt University School of Physical Education and Sports. The e-learning attitude scale which was developed by Wilkinson, Roberts and While (2010) and adapted to Turkish by Haznedar and Baran (2012) was used in the study. The data were analyzed through SPSS 22 package program. For descriptive data analysis; ANOVA and Independent Sample T test were applied. The result of the one-way analysis of variance showed that the Physical Education Teaching and Sports Management departments had higher scores than the Coaching Department. In this context, according to the results obtained from the research, it can be said that Coaching Department had lower score than the other two departments because of the fact that there were more courses requiring technical skills compared to the Physical Education Teaching and Sports Management departments.
\end{abstract}

Keywords: university students, e-learning, information technologies, attitude

\section{Introduction}

Along with globalization, there have been changes in many areas with the rapid developments occurring in the fields of Internet, information and communication technologies. With these changes, it is seen that there is an increase in the usage of information technologies in the field of education. With these changes, the field of education has started to shift to electronic environment. The digitalization of education has emerged as a new education-teaching model, namely e-learning, which gathers students and teachers from different locations, and enables instant communication between students and teachers.

E-learning is the execution of learning in qualified environments independent of time and place through computer and the Internet (Emrecik \& Ozan, 2019). E-learning can provide a learning structure which can be used in any environment that can benefit from computers and similar technologies at all ages. Therefore, it is an educational platform which can be useful in all learning processes before and after school (Yamamoto et al., 2010). E-learning is increasingly present in the framework of modern education approach (Yurdugül \& Demir, 2017). One of the important factors encountered in e-learning, which is becoming increasingly important in educational environments, is the student. The interests, expectations and needs of students vary greatly according to the traditional education approach (Erdoğan et al., 2007; Frith \& Kee, 2003; Glenn, 2001). Along with these differences, attitudes influence success in e-learning; because in an educational environment where student attitudes are not taken into account, it is difficult to create teaching experiences (Küçükahmet, 1997). As it can be understood, one of the issues to be examined is the attitude factor affecting the usage of e-learning. If institutions become aware of students' attitudes towards this teaching style, it may be easier to design and implement appropriate learning environments (Özgür \& Tosun, 2010). In line with all this information, the aim of the research is to determine the attitudes of physical education and sports school students towards e-learning.

\subsection{Literature Review}

E-learning is defined as the usage of information technologies through the Internet to provide information and provide educational opportunities to individuals (Welsh et al., 2003). A good design is an innovative approach which centers the student, facilitates and provides interactive learning environments; making use of learning 
materials suitable for flexible and open learning environments along with various digital technology features and resources, anywhere and anytime (Khan, 2005). Along with the environments it offers, students increase their knowledge and develop their skills with a wide range of technological applications, strategies and tools (Khan, 2001). Today, e-learning applications are utilized in many programs at all educational levels from primary to higher education and are rapidly becoming widespread. Many content designs related to any subject or course, are made by different institutions (Demiray et al., 2011).

The realization of teaching activities in e-learning is divided into two in terms according to the way of communication in e-learning. These two generally accepted forms are; simultaneous (synchronous) E-learning and nonsynchronous (asynchronous) E-learning. Simultaneous (synchronous) E-learning involves the exchange of ideas and information with one or more participants at the same time. It facilitates efficient education and offers both students and teachers opportunities to network, share and collaborate in real time (Higley, 2013). Nonsynchronous (asynchronous) e-learning involves lesson-related relationships between students and teachers, although participants cannot be online at the same time (Hrastinski, 2008).

Attitude can be defined as the possible behavior which an individual is expected to present in the face of a situation, event or phenomenon (İnceoğlu, 2010). It can be said that the degree of positive or negative attitudes of students towards e-learning will affect students' tendency towards using e-learning to a greater extent (Liaw, Huang, \& Chen, 2007). It is thought that determining the attitudes of physical education and sports school students towards e-learning will benefit to design teaching environments more efficiently.

\section{Method}

\subsection{Aim of the Study}

It is important to develop the attitudes of young people towards e-learning positively, to reach the goals of education programs, to share information and to realize the idea of e-learning reaching large masses. The study aims to investigate the attitudes of university students who have received sports education towards E-learning.

\subsection{Model of the Study}

The present study which evaluates the attitudes of university students studying at the school of physical education and sports towards e-learning, a quantitative research model was applied.

\subsection{Data Collection Method and Questionnaires}

Data collection method through questionnaire was used in the data collection phase of the research. The survey form consisted of two parts. In the first part of the survey, demographic questions were asked. In the second part of the survey form, the e-learning attitude scale was used to determine the attitudes of the physical education and sports school students towards e-learning.

The e-learning attitude scale developed by Wilkinson, Roberts and While (2010) and adapted into Turkish by Haznedar and Baran (2012) was used in the study. For the reliability estimation of the scale, Cronbach Alpha coefficient was calculated as 0.93 for 10 positive items in the scale; and 0.84 for 10 negative items in the scale. Cronbach Alpha coefficient was found to be 0.93 for a total of 20 items in the scale.

\subsection{Population and Sample}

The population of the study was comprised of 315 students who were selected via random sampling method, who studied in Bayburt University School of Physical Education and Sports, and the sample in School of Physical Education and Sports. Random sampling method is a sampling method that shows a situation where every member in the universe has the chance to be selected equally and independently (Altunışı et al., 2012). There are 628 students actively attending Bayburt University School of Physical Education and Sports. In Bayburt University School of Physical Education and Sports, there are students who study in the first, second, third and fourth grade in the department of coaching education, in the first and second grade in the Department of Physical Education, and only in the first grade in the Department of Sports management.

\subsection{Data Collection and Analysis}

The data were analyzed via the SPSS 22 package program. For descriptive data analysis; Independent Sample T test and ANOVA were performed to determine frequency, percentage, mean and standard deviation.

\section{Results}

The average age of the participants in the study was found to be 21.5 . Of the participants, $151(47.9 \%)$ were women, $164(52.1 \%)$ were men, $189(60 \%)$ were in coaching, 64 (20.3\%) were in sports management, $62(19.7 \%)$ in physical education; $151(47.9 \%)$ in the first grade, $77(24.4 \%)$ in the second grade, $46(14.6 \%)$ in the third 
grade, and $41(13 \%)$ in the fourth grade.

Table 1. The comparison results of the participants' sub-dimension scores of attitudes towards e-learning scale according to genders

\begin{tabular}{lllllll}
\hline & Gender & $\mathrm{N}$ & $\mathrm{X}$ & $\mathrm{SD}$ & $\mathrm{t}$ & $\mathrm{p}$ \\
\hline E-learning Tendency & Female & 151 & 3.2788 & .93713 & -.151 & .88 \\
& Male & 164 & 3.2945 & .90630 & & \\
E-learning Avoidance & Female & 151 & 2.5477 & .83441 & -1.26 & .21 \\
& Male & 164 & 2.6622 & .77833 & & \\
\hline
\end{tabular}

Table 1 shows the results of independent groups t-test used in comparing the subscale scores of the attitude scale towards e-learning of the participants who participated in the study according to gender. In the analysis results, no significant difference was found in terms of gender in the sub-dimension of E-learning Tendency and E-learning Avoidance $(\mathrm{p}>.05)$.

Table 2. The comparison results of the participants' sub-dimension scores of attitudes towards e-learning scale according to the department

\begin{tabular}{llllllll}
\hline & Department & $\mathrm{N}$ & $\mathrm{X}$ & $\mathrm{SD}$ & $\mathrm{F}$ & $\mathrm{P}$ & Difference \\
\hline E-learning Tendency & Coaching & 189 & 3.3683 & .92037 & 2.78 & .064 & \\
& Physical Education and Sports & 62 & 3.0532 & .82853 & & & \\
& Teaching & & & & & & \\
& Sports Management & 64 & 3.2734 & .97480 & & & $2>1$ \\
E-learning Avoidance & Coaching & 189 & 2.428 & .78619 & 12.75 & .000 & $3>1$ \\
& Physical Education and Sports & 62 & 2.921 & .70132 & & & \\
& Teaching & & & & & & \\
& Sports Management & 64 & 2.8328 & .82213 & & & \\
\hline
\end{tabular}

Note. 1) Coaching, 2) Physical Education and Sports Teaching, 3) Sports Management.

Table 2 shows the results of the ANOVA, which was used to compare the E-Learning Tendency and E-Learning Avoidance sub-dimension scores according to the department of the participants. The results show that while there is no difference in the E-Learning Tendency subscale scores, the E-Learning Avoidance subscale scores differ according to the status of the department $(\mathrm{p}<.05)$. According to the post hoc (Scheffe) test results to determine the source of the difference between the groups; statistically significant differences were found between "Coaching" and "Physical Education Teaching;" and "Coaching" and "Sports Management" in e-Learning Avoidance subscale scores $(\mathrm{p}<.05)$.

Table 3. The comparison results of the participants of the study regarding the sub-dimension scores of attitudes towards e-learning scale according to their grades

\begin{tabular}{|c|c|c|c|c|c|c|c|}
\hline & Grade & $\mathrm{N}$ & $\mathrm{X}$ & $\mathrm{SD}$ & $\mathrm{F}$ & $\mathrm{P}$ & Difference \\
\hline \multirow[t]{4}{*}{ E-learning Tendency } & 1st Grade & 151 & 3.1450 & .85484 & 26.67 & .00 & $2>1.4$ \\
\hline & 2nd Grade & 77 & 3.4909 & 69589 & & & $3>1.2 .4$ \\
\hline & 3rd Grade & 46 & 4.0522 & .70702 & & & $1>4$ \\
\hline & 4th Grade & 41 & 2.5683 & 1.02918 & & & \\
\hline \multirow[t]{4}{*}{ E-learning Avoidance } & 1st Grade & 151 & 2.8656 & .74225 & 20.26 & .00 & $1>3.4$ \\
\hline & 2nd Grade & 77 & 2.6351 & .72161 & & & $2>3$ \\
\hline & 3rd Grade & 46 & 1.9370 & 63047 & & & $4>3$ \\
\hline & 4th Grade & 41 & 2.3561 & .87637 & & & \\
\hline
\end{tabular}

Note. 1) 1st Grade, 2) 2nd Grade, 3) 3rd Grade, 4) 4th Grade.

Table 3 shows the results of ANOVA, which is used to compare the E-Learning Tendency and E-Learning Avoidance subscale scores according to grade. The results show that E-Learning Tendency and E-Learning Avoidance subscale scores differ according to the participants' grades $(p<.05)$. According to the post hoc (Scheffe) test results to which was applied to determine the source of the difference between the groups, there were statistically significant differences between "1st Grade" and "4th Grade", "2nd Grade" and "1st Grade" and 
"4th Grade", 3rd Grade and "1st Grade", 2nd Grade and 4th Grade. In E Learning Avoidance subscale scores, there were also statistically significant scores between "1st Grade" and "3rd Grade;" and "4th Grade", "2nd Grade" and "3rd Grade" and "4th Grade" and "3rd Grade" $(\mathrm{p}<.05)$.

\section{Discussion and Conclusion}

According to the findings obtained from the study results, there was not a significant difference in gender regarding E-learning Tendency and E-learning Avoidance. There are studies with similar results in the literature. Çetin (2018) did not find any difference according to the gender variable regarding the total score of the attitude scale towards e-learning in the study they conducted on students studying in maritime high school. In the study conducted by Demir (2013), in which the levels of acceptance of the e-learning tools students studying at the faculty of education were examined in terms of various variables, no difference was found regarding the gender variable. There are also studies with different results in the literature. Aras (2019) found that male students had a higher score in sub-dimension of e-learning tendency and no difference in sub-dimension of e-learning avoidance in the study conducted on university students who studied sports. In the study conducted by Haznedar (2012), where they examined the university students' total score of the attitude towards e-learning, there was a significant difference in terms of gender and male students' attitudes towards e-learning were more positive than female students. Sezer (2016) concluded that male students had more positive attitudes towards e-learning than female students in terms of gender variable in their study on medical students. Tekinarslan (2008) reported that male students' attitudes towards web-based learning were more positive than female students. According to the results obtained from the study, it is thought that there is no difference between women and men in the formation of attitudes towards e-learning and they may show similar attitudes towards e-learning.

The results regarding the department variable revealed that there was no difference in the E-Learning Tendency sub-dimension scores, whereas the Sports Management and Physical Education and Sports Teaching departments had higher scores than the Coaching department. There are also studies in the literature with different results. Demir (2013) did not find any difference according to the variable of the department in the study where they examined acceptance levels of e-learning tools. In the study conducted by Aras (2019) on university students studying sports, it was determined that the students who were educated in sports management had higher scores than the students who were trained in sports management and recreation department, and that there was no difference in the e-learning avoidance sub-dimension. Sabah (2013) stated that there was a positive relationship between technical skills and students' attitudes towards e-learning. In this context, according to the results obtained from the research, it can be said that the Coaching department had lower scores than the other two departments because of the fact that there are more courses requiring technical skills compared to the Physical Education and Sports Teaching and Sports Management departments.

When the results were analyzed according to the grade variable, there were statistically significant differences in"1st Grade" and "4th Grade", "2nd Grade", "1st Grade" and "4th Grade" in "3rd Grade" and "1st Grade", "2nd Grade" and "4th Grade" regarding E-learning Tendency; while there were statistically significant differences in the in "1st Grade," "3rd Grade" and "4th Grade," "2nd Grade" and "3rd Grade;" "4th Grade" and "3rd Grade" regarding E-learning Avoidance. There are studies with similar results in the literature. According to the results obtained from the study conducted by Haznedar (2012) and evaluated the total score of the attitude scale of university students towards e-learning, the results were in favor of 4th grade among 4th grade, 1st grade and 2nd grade; the 3rd grade between 2 nd grade and 3rd grade. Studies with different results are also available in the literature. Aras (2019) did not find any difference between the grade levels in their study on university students studying sports. Sezer (2016) did not find any difference regarding grade levels in their study on medical students. According to the results obtained from the study, it can be said that the education the students receive may have positive or negative effects on the attitudes towards the e-learning according to the content of the grade-based curricula.

In conclusion, it can be said on the basis of the findings that the departments and grade of students have an influence on the formation of their attitudes towards E-learning while the gender variable has no effect on the formation of their attitude towards E-learning. The content of the education which students receive is thought to be an effective factor in the formation of students' attitudes towards e-learning. In this context, it is thought that there will be a positive increase in students' attitudes towards e-learning if the course contents are suitable for e-learning. In future studies, applications to larger sample groups are recommended. It is recommended to apply studies to compare students studying in different faculties and students studying in sports sciences. 


\section{References}

Altunışık, R., Coşkun, R., Bayraktaroğlu, S., \& Yıldırım, E. (2012). Sosyal bilimlerde araştırma yöntemleri (7. bask1). İstanbul: Sakarya Kitabevi.

Aras, E. (2019). Spor eğitimi kurumlarında görev yapan akademik personel ve spor ĕgitimi gören öğrencilerin uzaktan eğitime yönelik görüşlerinin incelenmesi. Yüksek lisans tezi, Fırat Üniversitesi Sağlık Bilimleri Enstitüsü.

Çetin, U. (2018). Denizcilik Lisesi Öğrencilerinin E-Öğrenmeye Yönelik Tutumlarının Farklı Değişkenler Açısından İncelenmesi. Yüksek Lisans Tezi, Bahçeşehir Üniversitesi Eğitim Bilimleri Enstitüsü.

Demir, M. (2013). Eğitim Fakültesi Öğrencilerinin E-Öğrenme Araçlarını Kabul Düzeylerinin Çeşitli Değişkenler Açısından İncelenmesi. Yüksek lisans tezi, Sakarya Üniversitesi Eğitim Bilimleri Enstitüsü.

Demirci, B. B., Yamamoto, G. T., \& Demiray, U. (2011). Türkiye'de E-ögrrenme Gelişmeler ve Uygulamalar II. Eskişehir: Anadolu Üniversitesi İletişim Bilimleri Fakültesi Yayınları.

Emrecik, V., \& Ozan, Ö. (2019). E-Öğrenme Ortamında Kullanılan Ders Anlatım Videolarındaki Sözsüz İletişim Becerilerinin Öğrenci Bağlılığına Etkisi. Eskişehir Osmangazi Üniversitesi Sosyal Bilimler Dergisi, 20 (Özel Say1), 667-690. https://doi.org/10.17494/ogusbd.553853

Erdoğan, Y., Bayram, S., \& Deniz, L. (2007). Web tabanlı öğretim tutum ölçeği: Açıklayıcı ve doğrulayıcı faktör analizi çalışması. Uluslararası Insan Bilimleri Dergisi, 4(2), 1-14.

Frith, K. H., \& Kee, C. (2003). The Effect of Communication on Nursing Student Outcomes in a Web-Based Course. Journal of Nursing Education, 42(8), 350-358.

Glenn, A. (2001). A Comparison of Distance Learning and Traditional Learning Environments. Unpublished Doctoral Thesis, Faculty of The Graduate School of Texas A\&M University, Texas.

Haznedar, Ö., \& Baran, B. (2012). Eğitim Fakültesi Öğrencileri İçin E-Öğrenmeye Yönelik Genel Bir Tutum Ölçeği Geliştirme Çalışması. Eğitim Teknolojisi Kuram ve Uygulama, 2(2), $42-59$. https://doi.org/10.17943/etku.84225

Higley, M. (2013). Benefits of synchronous and asynchronous e-learning. Retrieved April 8, 2020, from https://elearningindustry.com/benefits-of-synchronous-and-asynchronous-e-learning

Hrastinski, S. (2008). Asynchronous and synchronous e-learning. Educause Quarterly, 31(4), 51-55.

İnceoğlu, M. (2010). Tutum algı iletişim. Ankara: Beykent Üniversitesi Yayınevi.

Khan, B. H. (2001). Web-based training. Englewood Cliffs, NJ: Educational Technology Publications.

Khan, B. H. (Ed.). (2005). Managing e-learning: Design, delivery, implementation, and evaluation. IGI Global. https://doi.org/10.4018/978-1-59140-634-1

Küçükahmet, L. (1997). Öğretim İlke ve Yöntemleri. Ankara: Gazi Büro Yayınevi.

Liaw, S. S., Huang, H. M., \& Chen, G. D. (2007). Surveying instructor and learner attitudes toward e-learning. Computers ve Education, 49, 1066-1080. https://doi.org/10.1016/j.compedu.2006.01.001

Özgür, H., \& Tosun, N. (2010). İnternet destekli eğitimin e-öğrenme tutumlarına etkisi. XV. Türkiye'de Internet Konferansi, 2-4.

Sabah, N. M. (2013). Students' attitude and motivation towards e-learning. In Proceedings of the First International Conference on Applied Sciences Gaza-Palestine.

Sezer, B. (2016). Faculty of medicine students' attitudes towards electronic learning and their opinion for an example of distance learning application. Computers in Human Behavior, 55, 932-939. https://doi.org/10.1016/j.chb.2015.10.018

Tekinarslan, E. (2008). Attitudes of Turkish Distance Learners Toward Internet Based Learning: An Investigation Depending on Demographical Characteristics. Turkish Online Journal of Distance Education, 9(1), 67-84.

Welsh, E. T., Wanberg, C. R., Brown, K. G., \& Simmering, M. J. (2003). E - learning: emerging uses, empirical results and future directions. International Journal of Training and Development, 7(4), $245-258$. https://doi.org/10.1046/j.1360-3736.2003.00184.x

Wilkinson, A., Roberts, J., \& While, A. E. (2010). Construction of an instrument to measure student information and communication technology skills, experience and attitudes to e - learning. Computers in Human Behavior, 26, 1369-1376. https://doi.org/10.1016/j.chb.2010.04.010 
Yamamoto, G. T., Demiray, U., Kesim, M., Yuzer, T. V., Demirci, B. B., \& Eby, G. (Eds.). (2010). Türkiye'de e-ögrrenme: gelişmeler ve uygulamalar (Vol. 155). Efil Yayınevi.

Yurdugül, H., \& Demir, Ö. (2017). Öğretmen yetiştiren lisans programlarındaki öğretmen adaylarının e-öğrenmeye hazır bulunuşluklarının incelenmesi: Hacettepe üniversitesi örneği. Hacettepe Üniversitesi Ĕ̈itim Fakültesi Dergisi, 32(4), 896-915. https://doi.org/10.16986/HUJE.2016022763

\section{Copyrights}

Copyright for this article is retained by the author, with first publication rights granted to the journal.

This is an open-access article distributed under the terms and conditions of the Creative Commons Attribution license (http://creativecommons.org/licenses/by/4.0/). 